\title{
Graphene oxide arms oncolytic measles virus for improved effectiveness of cancer therapy
}

Mao Xia ${ }^{1 \dagger}$, Dongjun $\mathrm{Luo}^{2 \dagger}$, Jie Dong ${ }^{3 \dagger}$, Meihong Zheng ${ }^{3}$, Gang Meng ${ }^{4}$, Junhua $\mathrm{Wu}^{3^{*}}$ and Jiwu Wei ${ }^{3^{*}}$

\begin{abstract}
Background: Replication-competent oncolytic viruses (OVs) have been proven to be a potent anticancer weapon for clinical therapy. The preexisting neutralizing antibody in patients is a big challenge for oncolytic efficacy of OVs. Graphene oxide sheets (GOS) possess excellent biological compatibility and are easy to decorate for targeted delivery.

Methods: We generated PEI-GOS-PEG-FA (Polyethyleneimine-Graphene oxide sheets-Polyethylene glycol-Folic acid). After intravenous injection, the distribution of PEI-GOS-PEG-FA in tumor-bearing mice was visualized by the IVIS Lumina XR system. Then, the oncolytic measles virus (MV-Edm) was coated with PEI-GOS-PEG-FA to form a viral-GOS complex (GOS/MV-Edm). The oncolytic effects of GOS/MV-Edm were investigated both in vitro and in vivo.

Results: GOS/MV-Edm exhibited higher infectivity and enhanced oncolysis. In tumor-bearing mice, GOS/MV-Edm had significantly elevated viral replication within the tumor mass, and achieved an improved antitumor effect. Then, we confirmed that GOS/MV-Edm entered cancer cells via the folate receptor instead of CD46, a natural cognate receptor of MV-Edm. GOS/MV-Edm remained the infectivity in murine cells that lack CD46. Finally, we found that GOS/MV-Edm was effectively protected from neutralization in the presence of antiserum both in vitro and in vivo. In passively antiserum immunized tumor-bearing mice, the survival was remarkably improved with intravenous injection of GOS/MV-Edm.
\end{abstract}

Conclusion: Our findings demonstrate that GOS/MV-Edm displays significantly elevated viral replication within the tumor mass, leading to an improved antitumor effect in solid tumor mouse model. Our study provided a novel strategy to arm OVs for more efficient cancer therapy. That may become a promising therapeutic strategy for cancer patients.

Keywords: Oncolytic measles virus, Delivery vector, Graphene oxide sheets, Targeted cancer therapy

\section{Background}

The attenuated measles virus, the vaccine strain Edmonston B (MV-Edm), is an oncolytic naked-stranded RNA virus that has been used in clinical trials [1]. Replicating oncolytic viruses has emerged as a promising method for the treatment of many malignancies $[2,3]$. These viruses can overcome the problem of limited delivery of therapeutic agents because, in principle, the successful infection of only a few tumor cells at the initiated stage should be enough for the virus to spread among most tumor cells [4]. In animal models, MV-Edm has been shown to have oncolytic activity against human malignant glioma,

\footnotetext{
* Correspondence: wujunhua@nju.edu.cn; wjw@nju.edu.cn

${ }^{\dagger}$ Mao Xia, Dongjun Luo and Jie Dong contributed equally to this work.

${ }^{3}$ Jiangsu Key Laboratory of Molecular Medicine, Medical School of Nanjing

University, Nanjing 210093, China

Full list of author information is available at the end of the article
}

lymphoma, ovarian cancer, multiple myeloma, fibrosarcoma and cutaneous T-cell lymphoma [5-9]. Moreover, a variety of replication-competent oncolytic viruses are being investigated. In particular, in October 2015, the US Food and Drug Administration (FDA) approved an oncolytic virotherapy treatment, talimogene laherparepvec (T-VEC), for patients with relapsed and unresectable melanoma [10].

As for replicating oncolytic viruses, host immune response and cellular barriers substantially limit MVEdm infection and intratumoral spread, respectively [11]. MV-Edm is readily neutralized by serum antibodies and cleared by the human immune response. According to current virotherapy treatments, various cell carriers have been used to protect therapeutic oncolytic viruses from immune clearance and to deliver the viruses to tumor 
loci $[6,12,13]$. These cellular carriers include blood outgrowth endothelial cells, mesenchymal stromal cells, and osteosarcoma cells $[6,13,14]$. However, conventional cell carriers suffer from several limitations, such as clinical, logistical, immunological and ethical concerns [15, 16]. To address these limitations, researchers have sought to develop other novel oncolytic virus carriers.

Recently, nanomaterials, including microspheres, liposomes, and graphene oxides, have attracted significant attention as promising nanovehicles due to advantages in their synthesis, functional decoration, uniformity and cost-effectiveness [17-20]. Therefore, nanovehicles have been developed for the targeted delivery of many therapeutic agents, including small drug molecules, antibodies, DNA, proteins and genes [18, 21, 22].

However, unlike general agents, oncolytic viruses have distinct properties in their biological activity, have a specific size, and are sensitive to physical and chemical conditions (i.e., they are easily inactivated). These challenges and limitations have inspired further investigation of nanovehicles. Among the various nanovehicles that have been tested, graphene oxide has several outstanding properties for therapeutic delivery and biological applicability, such as high surface area, appropriate surface chemistry and number of layers, biological compatibility, easy functionalization, high purity and strong capacity in adsorption [23-25]. Sun et al. first reported that graphene oxide sheets (GOS) functionalized with antibodies could be noncovalently loaded with the cancer drug doxorubicin for selective targeting of cancer cells [26]. The researchers then applied graphene sheets for gene delivery $[22,27,28]$. In addition, due to the overexpression of folic acid (FA)-binding proteins on the surface of many types of cancer cells, FA functionalization on GOS (folic acid-GOS) is one of the most common strategies for cancer-targeting delivery [19].

In this study, to improve the targeting delivery of oncolytic viruses, nontoxic, multifunctionalized GOS with polyethylene glycol (PEG), polyethyleneimine (PEI) and FA (PEI-GOS-PEG-FA) were employed to encapsulate MV$\mathrm{Edm}$. PEG was used to increase the stability of graphene in physiological solutions; PEI was used as an adhesion promotor; and FA was used as the targeting agent. PEI-GOSPEG-FA-decorated MV-Edm (GOS/MV-Edm) is similar to nano-Trojan horses. The encapsulation efficacy, oncolytic efficiency, tumor targeting and effectiveness in protecting against neutralizing antibodies in serum were evaluated for this type of nano-Trojan horse. That may become a novel, promising therapeutic strategy for cancer patients.

\section{Methods}

\section{Cell lines and cell culture}

The human lung adenocarcinoma cell lines A549 (CCL185), HeLa (CCL-2), LLC (CRL-1642), 4 T1 (CRL-2539) and Vero African green monkey kidney cells (CCL-81) were obtained from American Type Culture Collection (ATCC, Manassas, VA). The cells were maintained in Dulbecco's modified Eagle's medium (DMEM) supplemented with $0.1 \mathrm{mM}$ nonessential amino acids, $5 \%$ fetal bovine serum, and penicillin-streptomycin (all from Invitrogen).

\section{Viruses}

MV-Edm and MV-Edm expressing the reporter gene luciferase (MV-Edm-Luc, kindly provided by S. Russell, Mayo Clinic, MN, USA) were propagated in Vero cells with a multiplicity of infection (MOI) of 0.02 in $2 \mathrm{ml}$ OptiMEM (Invitrogen, $31,985-062$ ) at $37^{\circ} \mathrm{C}$ for $3 \mathrm{~h}$. The medium was changed to DMEM supplemented with $2 \%$ FCS, and the cells were incubated at $37^{\circ} \mathrm{C}$ for 1 day before being transferred to $32^{\circ} \mathrm{C}$ for another day. The cells were harvested, and the viral particles were released by 2 cycles of snap freezing in liquid nitrogen and thawing in a $37^{\circ} \mathrm{C}$ water bath. The viral titers were determined by $50 \%$ end-point dilution assays (TCID50) on the Vero cells.

\section{Reagents}

The reagents used in this study are listed as follows. Graphene oxide sheets (GOS) were obtained from Nanjing XFNANO Materials Tech Co., Ltd. Six-armed PEG with a molecular weight (MW) of $10 \mathrm{kDa}$ was purchased from Sunbio. Rhodamine-PEG-NHS $(5 \mathrm{kD})$ was purchased from Ponsure. Branched PEI with an MW of $25 \mathrm{kDa}, \mathrm{N}-(3-$ dimethylaminopropyl- $N^{\prime}$-ethylcarbodiimide) hydrochloride (EDC), $N$-hydroxysuccinimide (NHS), 2-morpholinoethane sulfonic acid monohydrate (MES), folate (FA), dimethylformamide (DMF), N, N-diisopropylethylamine (DIPEA) and triethylamine were purchased from Sigma-Aldrich. All other chemicals were obtained from Aladdin. All solvents were used directly without further purification. All reagents were formulated as recommended by their suppliers.

\section{Cell viability assay}

To measure viability following MV-Edm or GOS/MVEdm infection. Cells were harvested with trypsin/EDTA and stained with trypan blue. The cell viability was determined by the trypan blue exclusion assay according to established protocols.

\section{Preparation of small GOS and ultrasmall carboxylated GOS}

GO flakes $(100 \mathrm{mg})$ were added to $10 \mathrm{ml}$ of deionized (DI) water under vigorous stirring. The GO flakes were then dispersed in an ultrasonic water bath for $180 \mathrm{~min}$ at room temperature to afford a solution of GOS with a final concentration of $5 \mathrm{mg} / \mathrm{ml}$. The mixture was then centrifuged $(12,000 \times \mathrm{g}, 10 \mathrm{~min})$ and washed several times with DI water. To generate small GOS, the resultant 
GOS solution in DI water $(5 \mathrm{mg} / \mathrm{ml})$ was treated to another round of ultrasonication with an ultrasonic probe at $400 \mathrm{~W}$ for $60 \mathrm{~min}$ in an ice-water bath, followed by centrifuging at $12,000 \times \mathrm{g}$ for $30 \mathrm{~min}$. The small GOS were obtained from the supernatant, and the supernatant was diluted with DI water to a final volume of $20 \mathrm{ml}$. The preparation process of small GOS is illustrated in Fig. 1a.

To obtain carboxylated small GOS (schematic illustration of the preparation of carboxylated GOS is shown in Fig. 1b), $\mathrm{NaOH}(3.6 \mathrm{~g})$ was added in an ice-water bath to $20 \mathrm{ml}$ of the small GOS solution prepared in the previous step. Then, the mixture was heated to $55^{\circ} \mathrm{C}$ under magnetic stirring in an oil bath for $4 \mathrm{~h}$ to oxidize the $\mathrm{OH}$ groups to the $\mathrm{COOH}$ groups. $\mathrm{HCl}$ solution $(37 \%$ ( $\mathrm{vol} / \mathrm{vol}), 12 \mathrm{ml}$ ) was added to the solution to neutralize the $\mathrm{NaOH}$. To remove the salt, the product was washed by centrifugation at $12,000 \times \mathrm{g}$ for $10 \mathrm{~min}$, and DI water $(20 \mathrm{ml})$ was added six times, followed by treatment with an ultrasonic probe at $400 \mathrm{~W}$ for $60 \mathrm{~min}$ in an ice-water bath. The product was centrifuged at $30,000 \times \mathrm{g}$ for 45 min to generate ultrasmall carboxylated GOS in the supernatant, the concentration of which can be determined by its UV-visible NIR absorbance spectrum with a weight extinction coefficient of $47.6 \mathrm{mg} / \mathrm{ml} / \mathrm{cm}$ at 230 $\mathrm{nm}$ [29]. The preparation process of ultrasmall carboxylated GOS is illustrated in Fig. 1c.

\section{Conjugation of FA to amine-capped polyethylene glycol $\left(\mathrm{NH}_{2}\right.$-PEG-NH $\left.\mathrm{N}_{2}\right)$}

As shown in Fig. 1d, FA $(0.175 \mathrm{mmol})$, EDC $(0.25 \mathrm{mmol})$ and NHS $(0.25 \mathrm{mmol})$ were added to $50 \mathrm{ml}$ of a $4: 1 \mathrm{mix}-$ ture of water and dimethylsulfoxide (DMSO) in the presence of $10 \mathrm{mM}$ MES. After vigorous agitation and sonication for $10 \mathrm{~min}$, the reaction mixture was agitated overnight. Then, $100 \mu \mathrm{l}$ of triethylamine and $0.2526 \mathrm{mmol}$ of the six-armed PEG- $\mathrm{NH}_{2}$ were added to the reaction mixture, and it was stirred for an additional $24 \mathrm{~h}$ at room temperature. After the reaction, the small-MW compounds were removed from the solution by a dialysis bag $(\mathrm{MWCO}=2 \mathrm{kDa})$. The solution was condensed with an Amicon centrifugal filter device (Millipore, UFC910024, Billerica, MA). The PEG-FA product was obtained by lyophilization. The structure of PEG-FA was confirmed by Fourier transform infrared spectroscopy (FTIR) (Fig. 1e). Absorbance bands for PEG-FA were observed at 1690 $\mathrm{cm}^{-1}$ (-NH-CO-), $2872 \mathrm{~cm}^{-1}(\mathrm{C}-\mathrm{H})$ and $1100 \mathrm{~cm}^{-1}$ (C-OC). In addition, a peak at approximately $1536 \mathrm{~cm}^{-1}$ characteristic of FA, appeared in the spectrum, which suggests that FA was successfully bound to the PEG.

\section{Preparation of an ultrasmall PEI-GOS-PEG-FA conjugate}

PEG-FA (10 mg) was added to the solution of ultrasmall carboxylated GOS $(1 \mathrm{mg} / \mathrm{ml}, 10 \mathrm{ml})$ under ultrasonication in a bath sonicator at room temperature for $10 \mathrm{~min}$. EDC
(10 mg) was added to the mixture, and the mixture was ultrasonicated for an additional $10 \mathrm{~min}$, followed by treatment with an ultrasonic probe at $400 \mathrm{~W}$ for $15 \mathrm{~min}$ in an ice-water bath. After being stirred gently at room temperature for $10 \mathrm{~min}, 50 \mathrm{mg}$ of PEI in $1 \mathrm{ml}$ of water was added to $10 \mathrm{ml}$ of the GOS mixture, and the mixture was ultrasonicated in a bath sonicator for $10 \mathrm{~min}$. Then, $20 \mathrm{mg}$ of EDC was added, followed by another 10 min of ultrasonication in a bath sonicator and then treatment with an ultrasonic probe at $400 \mathrm{~W}$ for $15 \mathrm{~min}$ in an ice-water bath. After the addition of the second batch of EDC $(10 \mathrm{mg})$, the reaction solution was stirred gently overnight at room temperature. After treatment with an ultrasonic probe for $15 \mathrm{~min}$ in an ice-water bath, the solution was centrifuged at $30,000 \times \mathrm{g}$ for $45 \mathrm{~min}$ to remove any aggregates. The supernatant was collected and transferred to a 50-ml Amicon centrifugal filter device $(\mathrm{MWCO}=100 \mathrm{kDa})$. The device was centrifuged at $2000 \times \mathrm{g}$ for $10 \mathrm{~min}$. The volume of solution remaining in the filter was less than $1 \mathrm{ml}$. The filter device was then filled with $10 \mathrm{ml}$ of DI water, and the solution in the device was washed six times by repeating the centrifuging and water-adding steps to completely remove any PEG-FA, EDC and PEI in the obtained PEI-GOS-PEGFA solution. After the final washing step, the obtained PEI-GOS-PEG-FA solution was treated with an ultrasonic probe for $15 \mathrm{~min}$ in an ice-water bath, and the solution was then centrifuged at $100,000 \times \mathrm{g}$ for $45 \mathrm{~min}$. The solution of ultrasmall PEI-GOS-PEG-FA was obtained by collecting the supernatant. The preparation process of the PEI-GOS-PEG-FA solution and its schematic illustration are shown in Fig. If and g, respectively. The concentration of PEI-GOS-PEG-FA solution was determined by analyzing the UV-visible NIR absorbance spectrum (47.6 $\mathrm{mg} \mathrm{ml}^{-1} \mathrm{~cm}^{-1}$ at $230 \mathrm{~nm}$ ). Unless otherwise stated, the concentration of PEI-GOSPEG-FA used in the experiment was $1 \mathrm{mg} / \mathrm{ml}$.

\section{Conjugation of rhodamine to PEI-GOS-PEG-FA}

The PEI-GOS-PEG-FA solid product was obtained by lyophilization from the solution prepared in the previous step. PEI-GOS-PEG-FA (20 mg), rhodamine (1 mg) and DIPEA $(0.2 \mu \mathrm{l})$ were added to $0.5 \mathrm{ml}$ of DMF under dark conditions. After vigorous agitation, the reaction mixture was stirred gently overnight at room temperature in the dark. After sonication in a bath sonicator at room temperature for $1 \mathrm{~h}$, the small-MW compounds were removed from the reaction solution by a dialysis tubing $(\mathrm{MWCO}=10 \mathrm{kDa})$. Finally, PEI-GOS-PEG-FA labeled with the fluorescent dye rhodamine was obtained in the solution [30].

\section{Quantitative RT-PCR}

For quantitative RT-PCR (qPCR), total cellular RNA was extracted with TRIzol (Invitrogen, 15,596-026), and 
a

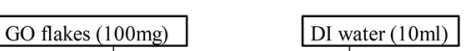

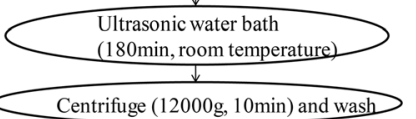

Centrifuge (12000g, 10min) and wash

$$
\text { GOS solution }
$$

Ultrasonication with a probe
(60 min, ice-water bath)

Centrifuge $(12000 \mathrm{~g}, 30 \mathrm{~min})$
collect the supernatant

$\frac{\downarrow}{\text { Small GOS solution }}$

c

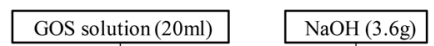

$$
\frac{\frac{\downarrow}{\text { Ice-water }}}{\text { bath } \downarrow}
$$
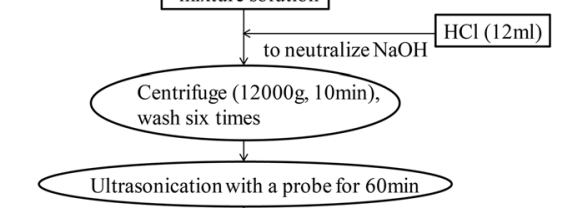

Ultrasonication with a probe for $60 \mathrm{~min}$

Centrifuge (30000g, $45 \mathrm{~min})$, collect the supernatant

Ultra-small carboxylated GOS

e

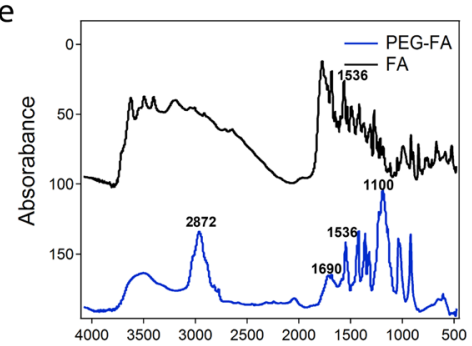

Wave number $\left(\mathrm{cm}^{-1}\right)$

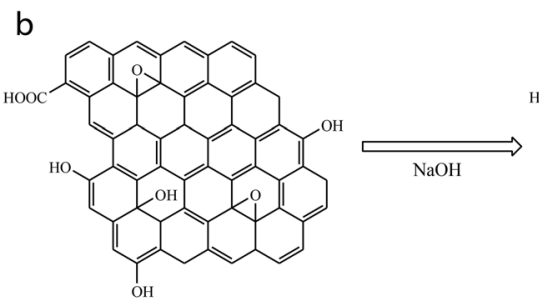

GOS

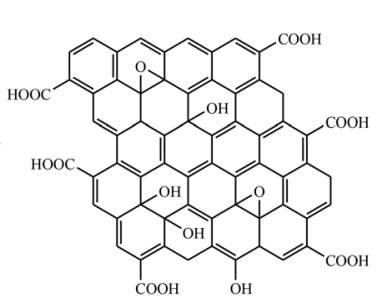

Small carboxylated GOS

d<smiles>Cc1cc(O)c2nc(C[IH]c3ccc(C(=O)NC(CO)CCO)cc3)ccc2c1</smiles>

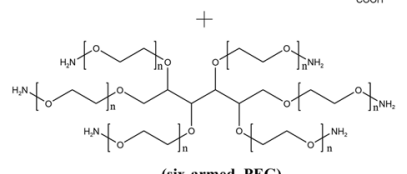

(six-armed PEG)

DMSO, NHS, EDC

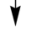

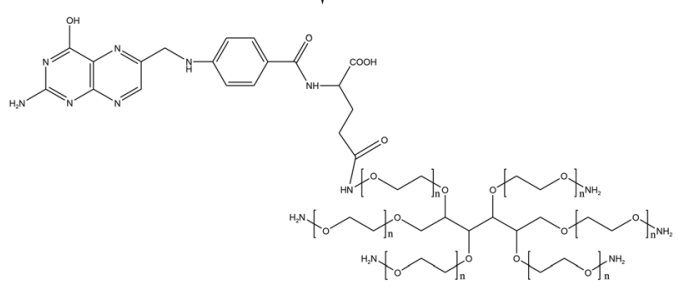

f

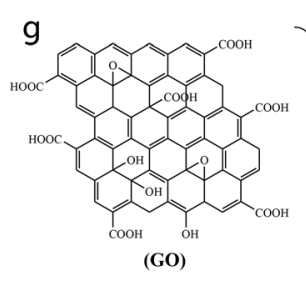

$\mathrm{NH}_{2}$-PEG-FA

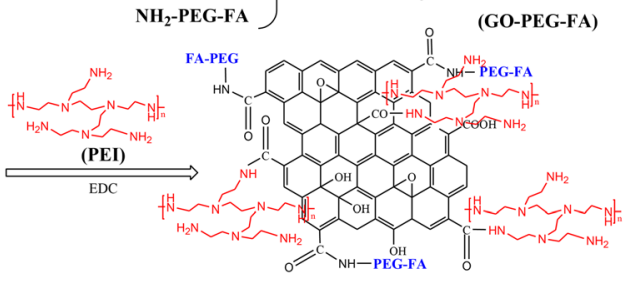

(PEI-GO-PEG-FA)

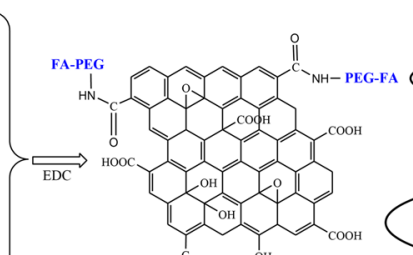

\section{\begin{tabular}{|l|l|l|l|l|}
\hline Carboxylated GOS $(1 \mathrm{mg} / \mathrm{ml}, 10 \mathrm{ml})$ & PEG-FA(10)-small PEI-GO-PEG-FA \\
\hline
\end{tabular}}

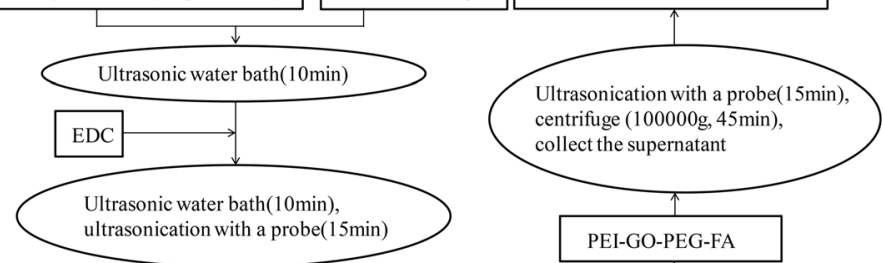

PEI-GO-PEG-FA

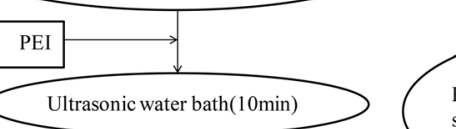

Repeat the centrifuging and water-adding steps in a filter device to remove any PEGFA, EDC and PEI
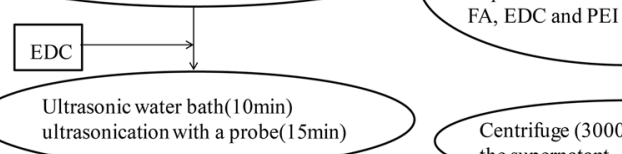

$+$

Centrifuge (30000g, $45 \mathrm{~min})$, collect the supernatant

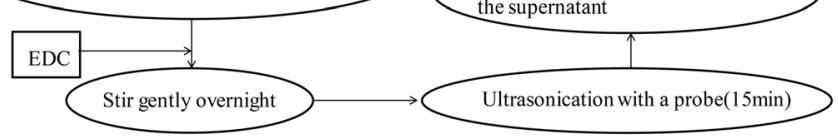

Fig. 1 (See legend on next page.) 
(See figure on previous page.)

Fig. 1 Preparation of PEI-GOS-PEG-FA. a The preparation process of small GOS. The rectangles represent the chemicals, and the circles represent the steps. $\mathbf{b}$ Schematic illustration of the preparation of small carboxylated GOS. The OH groups were oxidized to COOH groups on GOS by $\mathrm{NaOH}$. c The preparation process of ultrasmall carboxylated GOS. The rectangles represent the chemicals, and the circles represent the steps. $\mathbf{d}$ Schematic illustration of the preparation of PEG-FA. Only the structure of the main product, the active carboxyl-linked conjugate, is shown. e FTIR spectra of FA (black) and PEG-FA (blue). Absorbance bands for PEG-FA are observed at $1690 \mathrm{~cm}^{-1}$ (-NH-CO-), $2872 \mathrm{~cm}^{-1}$ (C-H) and $1100 \mathrm{~cm}^{-1}$ (C-O-C). In addition, a peak at approximately $1536 \mathrm{~cm}^{-1}$ characteristic of FA appears in the spectrum of PEG-FA. $\mathbf{f}$ The preparation process of PEI-GO-PEG-FA solution. The rectangles represent the chemicals, and the circles represent the steps. $\mathbf{g}$ Schematic illustration of the preparation of PEI-GOS-PEG-FA. PEG-FA and PEI were both connected to GO via an amide linkage between the amino groups on PEG-FA and PEl and the carboxylic groups on GO

$1 \mu \mathrm{g}$ of RNA was reverse-transcribed using the synthesis system (TaKaRa, DRR036A). qPCR was performed using the real-time PCR system (ABI 7300). Gene expression was calculated with the comparative $\mathrm{Ct}$ method and normalized to the endogenous levels of GAPDH. The primer sequences used for qPCR are listed in Table 1.

\section{Luciferase assay}

The luciferase activity of cells infected with MV-Edm expressing luciferase (MV-Edm-Luc) was monitored based on their luminescence following the addition of luciferin (Gold Biotechnology, St. Louis, MO, LUCK-1G) at a concentration of $150 \mu \mathrm{g} / \mathrm{ml}$ according to the instructions of the manufacturer.

\section{Animal studies}

Immunodeficient nude mice ((Foxn1nu) mut/mut male, 5-6 weeks old) obtained from the Model Animal Research Center of Nanjing University (Nanjing, China) were used for in vivo assays. All animal work was approved by the Animal Care Committee of Nanjing University and was carried out in accordance with Institutional Animal Care and Use Committee guidelines. The mice were injected subcutaneously with $5 \times 10^{6} \mathrm{HeLa}$ cells $/ 0.1 \mathrm{ml} /$ mouse in the left flank. On the 10th day, the tumors became visible. At that point, the mice were randomly assigned to different groups. The tumor volume was calculated using the following formula: $0.5236 \times \mathrm{L} 1(\mathrm{~L} 2)^{2}$, where L1 is the long diameter and L2 is the short diameter. Tumors were measured once every 3 days, and their survival was monitored daily. Mice exhibiting moribund behavior were euthanized.

\section{Transfer of antibodies against measles virus to mice}

Serum was isolated from a healthy donor with immunity to measles, inactivated at $56^{\circ} \mathrm{C}$ for $30 \mathrm{~min}$ and centrifuged

Table 1 Primers

\begin{tabular}{lll}
\hline & 5'-primer 1 & 3'-primer 2 \\
\hline GAPDH & CCACCCATGGCAA & TCTAGACGGCAGG \\
& ATTCCATGGCA & TCAGGTCCACC \\
MV-Edm N- & ACATTA & TाTCGCTTा \\
protein & GCATCTGAACTCGGTATCAC & GATCACCGTGTA \\
\hline
\end{tabular}

at $4000 \times$ g. To neutralize the MV-Edm in vivo, a group of mice bearing HeLa tumors was immunized by intraperitoneal injection of $500 \mu \mathrm{l}$ of human measles immune serum $18 \mathrm{~h}$ prior to injection of either MV-Edm or GOS/MVEdm.

\section{Visualization of $\mathrm{MV}$-Edm replication in vivo}

Fourteen days after injection of the HeLa cells, once the tumors were established, the mice received injections of MV-Edm or PEI-GOS-PEG-FA/MV-Edm (GOS/ MVEdm). Three days after this injection, the mice were anesthetized and injected intraperitoneally with D-luciferin (Gold Biotechnology, St. Louis, MO, LUCK-1G) and subjected to a luciferase assay using the IVIS Lumina XR system (Caliper Life Sciences, Hopkinton, MA). The level of firefly luciferase was expressed in terms of the ROI value, which was normalized to tumor volume.

\section{Statistical analysis}

Results are expressed as the mean \pm standard error of the mean (SEM). Student's t tests were used for statistical analyses. Survival data were compared using the log-rank test. $P$-values less than 0.05 were considered significant.

\section{Results}

Characterization of ultrasmall PEI-GOS-PEG-FA and its tumor-targeting capacity

GOS, carboxylated GOS and ultrasmall PEI-GOS-PEGFA conjugates are all highly stable in DI water (Fig. 2a). The size and $\zeta$-potential that signifies the electrophoretic mobility of the charged surface of the GOS, carboxylated GOS and PEI-GOS-PEG-FA were examined using a Zetasizer Nano ZSP instrument (Malvern, UK) [31]. The size of the small GOS was $153.1 \pm 7.2 \mathrm{~nm}$ and that of the ultrasmall carboxylated GOS was $94.1 \pm 4.2 \mathrm{~nm}$. As expected, the ultrasmall PEI-GOS-PEG-FA conjugate was only $25.4 \pm 4.2 \mathrm{~nm}$ (Fig. $2 \mathrm{~b}$ and Table 2 ). GOS showed a negative zeta potential of $-16.7 \pm 0.9 \mathrm{mV}$, while the zeta potential of carboxylated GOS was $-44.2 \pm 1.5 \mathrm{mV}$. However, the PEI-GOS-PEG-FA conjugate showed a high positive zeta potential, indicating that a considerable change in the surface charge of GOS occurred due to PEI conjugation (Fig. 2c and Table 3). X-ray photoelectron spectroscopy (XPS) was used to verify the immobilization 
a

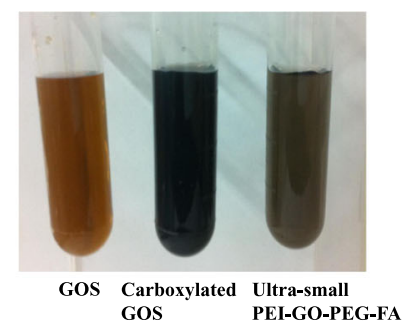

C

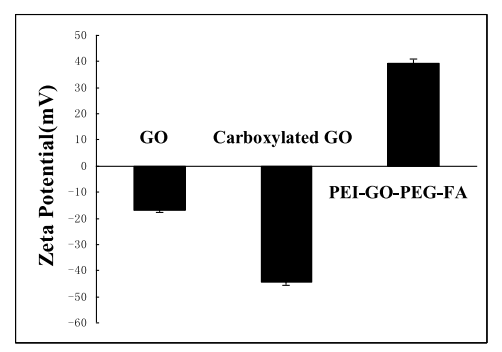

d

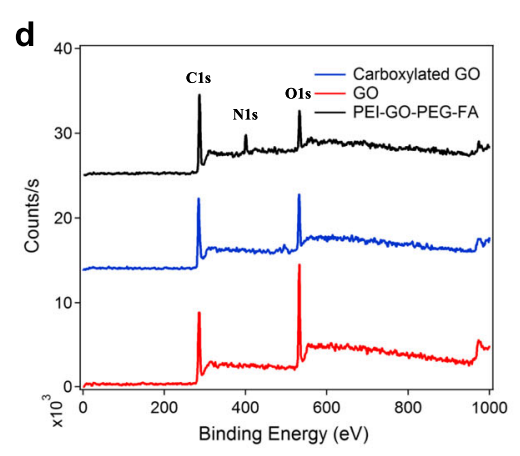

e

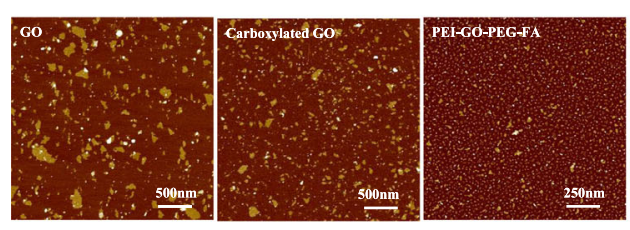

f

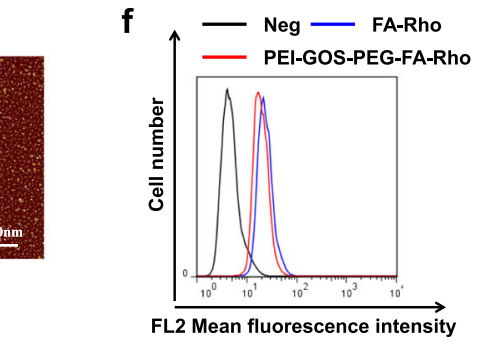

g
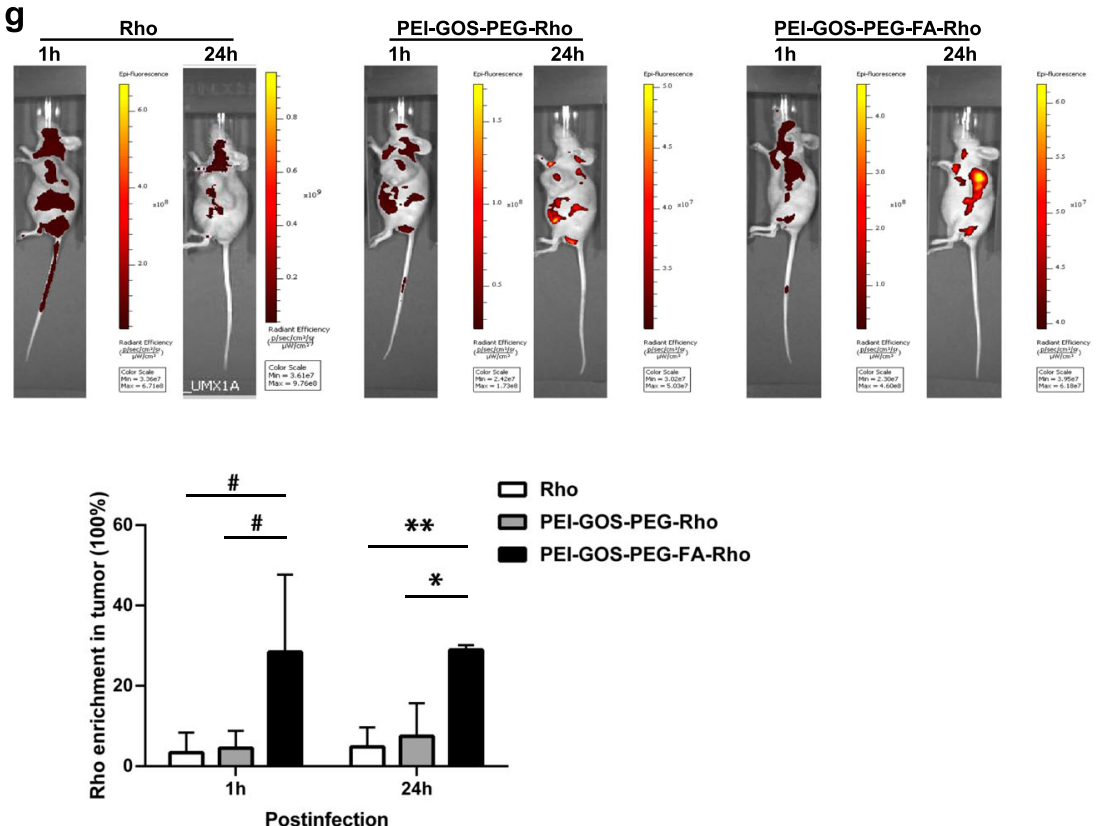

Fig. 2 (See legend on next page.)

b

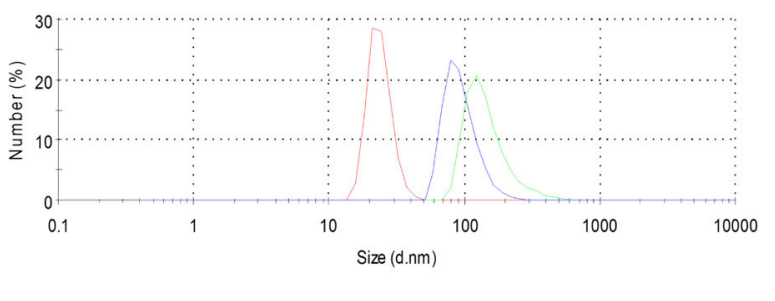


(See figure on previous page.)

Fig. 2 Characterization of ultrasmall PEI-GOS-PEG-FA and its tumor-targeting effect. a Photographs of GOS, carboxylated GOS and PEI-GO-PEG-FA in DI water show a visible color difference. b Representative diagram from Zetasizer Nano ZSP for the sizes of various GOS derivatives. c Zeta potential values of various GO derivatives. $\mathbf{d}$ XPS binding energy survey of the PEI-GO-PEG-FA conjugate (black), GOS (red) and carboxylated GOS (blue). e AFM images of small GOS, ultrasmall carboxylated GOS and PEI-GO-PEG-FA. f HeLa human cervical carcinoma cells largely express FR. FA and PEI-GOS-PEG-FA were labeled with rhodamine (FA-Rho and PEI-GOS-PEG-FA-Rho), a commonly used fluorescent dye. Cell-surface FR expression of the HeLa cells was determined by fluorescence-activated cell sorting analysis. $\mathbf{g}$ A total of $5 \times 10^{6} \mathrm{HeLa}$ cells/0.1 $\mathrm{ml} / \mathrm{mouse}$ was subcutaneously injected into the left flanks of 5- to 6-week-old male Foxn1nu mut/mut mice; 10 days later, the tumors became visible. The mice were randomly divided into three groups. PEI-GOS-PEG or PEI-GOS-PEG-FA was labeled with rhodamine; then, nude mice bearing HeLa human cervical carcinoma tumors were intravenously injected with Rho, PEI-GOS-PEG-Rho or PEI-GOS-PEG-FA-Rho (200 $\mu \mathrm{l}$ of a $0.15 \mathrm{mg} / \mathrm{ml}$ solution for each mouse; a dose of $20 \mathrm{mg} / \mathrm{kg}$ ) and then spectrally imaged by the IVIS Lumina XR system at $1 \mathrm{~h}$ and $24 \mathrm{~h}$ postinjection. The percentage of tumor enriched Rho was calculated by dividing the fluorence intensity in tumor by total (lower panel, $n=3) .{ }^{*} p<0.05,{ }^{* *} p<0.01$

of PEI on the GOS. As expected, an intense N-binding peak at $400 \mathrm{eV}$ corresponding to the $\mathrm{N} 1 \mathrm{~s}_{1 / 2}$ orbital was observed only in the PEI-GOS-PEG-FA conjugate and not in the GOS and carboxylated GOS, confirming the presence of PEI on the GOS (Fig. 2d) [32]. Atomic force microscopy (AFM) images (Fig. 2e) showed that the size of the PEI-GOS-PEG-FA sheets was much smaller than that of the starting GOS sample due to the ultrasonication that cleaved the graphene sheets.

To study the behaviors and biodistribution of PEIGOS-PEG-FA in vivo, we labeled PEI-GOS-PEG and PEI-GOS-PEG-FA with rhodamine (PEI-GOS-PEG-Rho and PEI-GOS-PEG-FA-Rho, respectively), a commonly used fluorescent dye. This strategy provides a reliable and convenient method for the real-time and in situ monitoring of animal models. Nude mice bearing human cervical carcinoma HeLa cells were intravenously injected with PEI-GOS-PEG-FA-Rho and then spectrally imaged by an IVIS Lumina XR system. Most HeLa human cervical carcinoma cells expressed folate receptor (FR) (Fig. 2f). As shown in Fig. 2g, PEI-GOS-PEG-FA-Rho was widely dispersed in the whole body of a mouse in the first $60 \mathrm{~min}$ postinjection (p.i.) and became enriched in the tumor over time. Prominent uptake of PEI-GOS-PEG-FA-Rho was observed in the tumor, while relatively low signals were observed in other parts of the mouse body at $24 \mathrm{~h}$ p.i. Mice injected with PEI-GOS-PEG-Rho or free Rho solutions at the same concentrations showed relatively lower fluorescent signaling intensity. These results suggest that PEI-GOS-PEG-FA-Rho has efficient tumor-targeting effects; in contrast, the results of the PEI-GOS-PEG-Rho and free Rho tests show limited tumor uptake in the absence of the targeting ligand.

Table 2 The sizes of various GO derivatives

\begin{tabular}{ll}
\hline & $\begin{array}{l}\text { Diameter }(\mathrm{nm}) \\
\text { Mean } \pm \text { s. d. }\end{array}$ \\
\hline GO & $153.1 \pm 7.2$ \\
Carboxylated GO & $94.1 \pm 4.2$ \\
PEI-GO-PEG-FA & $25.4 \pm 4.2$ \\
\hline
\end{tabular}

\section{MV-Edm can be effectively encapsulated in graphene oxide}

To evaluate the possibility of PEI-GOS-PEG-Rho for use as tumor-targeting carriers for MV-Edm, we first verified whether PEI-GOS-PEG-Rho can encapsulate MV-Edm. Using transmission electron microscopy, we observed that PEI-GOS-PEG-Rho was capable of encapsulating MV-Edm (Fig. 3). Furthermore, the size and zeta potential of MV-Edm, PEI-GOS-PEG-FA and GOS/MV-Edm

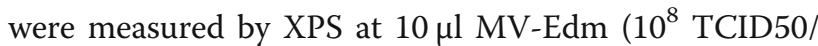
$\mathrm{ml})$ and GOS $(0.15 \mathrm{mg} / \mathrm{ml})$; the ratio is $\mathrm{v} / \mathrm{v}$. The size and zeta potential of GOS/MV-Edm were larger than those of unbound MV-Edm or PEI-GOS-PEG-Rho and were ratio dependent (Table 4). These results imply that the as-prepared PEI-GOS-PEG-Rho successfully capsulated MV-Edm; MV-Edm capsulated by PEI-GOS-PEG-FA is identified as GOS/MV-Edm.

\section{GOS/MV-Edm exhibits a more effective infectious and oncolytic capacity than MV-Edm in cancer cells}

Next, we investigated whether the successfully encapsulated MV-Edm (GOS/MV-Edm) retained its ability to infect cancer cells. HeLa and A549 cells strongly express the MV-Edm receptor (CD46), which allows the MVEdm to enter the cells. In Fig. 4a, HeLa and A549 cells were successfully infected with MV-Edm using GOS/ MV-Edm-eGFP. Interestingly, fluorescence microscopy showed that MV-Edm-eGFP spread more rapidly in GOS/MV-Edm-infected cells than in naked MV-Edminfected cells. MV-Edm-Luc replicated more rapidly in GOS/MV-Edm cells than in naked MV-Edm-infected cells, as shown in Fig. 4b. Furthermore, the oncolytic

Table 3 Zeta potential values of various GO derivatives

\begin{tabular}{ll}
\hline & Zeta Potential (mV) \\
\hline GO & Mean \pm s. d. \\
Carboxylated GO & $-16.7 \pm 0.9$ \\
PEI-GO-PEG-FA & $-44.2 \pm 1.5$ \\
\hline
\end{tabular}




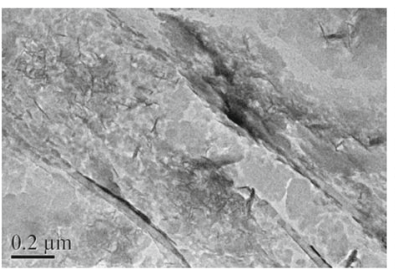

PEI-GOS-PEG-FA

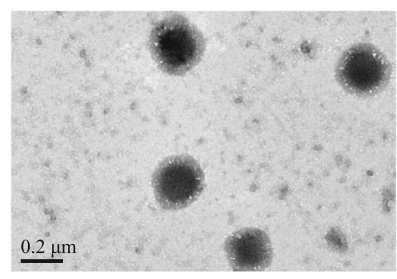

MV-Edm

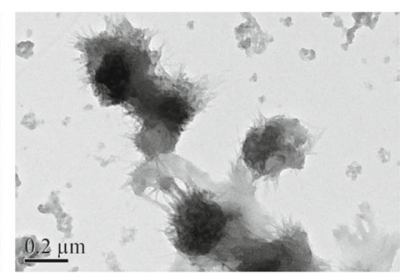

GOS/MV-Edm

Fig. 3 Encapsulation of MV-Edm in GOS. a Encapsulation of MV-Edm in PEI-GOS-PEG-FA was observed by transmission electron microscopy (TEM). Similar results were obtained in three independent experiments. Scale bars, $200 \mathrm{~nm}$

effect of GOS/MV-Edm was significantly stronger than that of naked MV-Edm in HeLa or A549 cells (Fig. 4c).

To confirm the antitumor effects of GOS/MV-Edm in vivo, we employed a nude murine model burdened with HeLa human cervical cancer cells infected with either GOS/MV-Edm or naked MV-Edm. On days 1 and 14 postinoculation of the HeLa cells, mice bearing HeLa tumors were treated with naked MV-Edm or GOS/MVEdm. GOS/MV-Edm was more efficient in replicating than naked MV-Edm in vivo (Fig. 4d). The tumor volumes observed in the two groups were significantly different. The volumes of the tumors in mice treated with GOS/MV-Edm were clearly smaller than those of the tumors treated with naked MV-Edm (Fig. 4e). These results indicate that MV-Edm encapsulated in PEI-GOSPEG-FA has a significantly more impactful oncolytic effect than naked MV-Edm in vitro and in vivo.

\section{PEI-GOS-PEG-FA encapsulated MV-Edm infects cells via the folate receptor}

FR is overexpressed in many cancer cells, which makes folate an attractive target for cancer therapies. HeLa and A549 cells positively express FR [33, 34]. To explore whether GOS/MV-Edm enabled the virus to enter the cells via the FR, HeLa and A549 cells were infected with GOS/MV-Edm or naked MV-Edm in FA-free DMEM or DMEM with high levels of FA (Fig. 5a). FA-free medium $\left(\mathrm{FA}^{-}\right)$was used to ensure the availability of FR on the surface of the FR-expressing cancer cells, and DMEM with abundant FA $\left(\mathrm{FA}^{+}\right)$was used to block the majority of the FRs on the cancer cell surfaces [35]. For naked MV-Edm infection, the cells in the $\mathrm{FA}^{+}$or $\mathrm{FA}^{-}$medium displayed almost identical syncytia and oncolytic effects. However, the syncytia and oncolytic effects of GOS/MV-
Edm in the $\mathrm{FA}^{-}$medium were significantly increased compared with those in the $\mathrm{FA}^{+}$group (Fig. $5 \mathrm{a}$ and b). The expression of $\mathrm{N}$ viral structural genes was quantified by qRT-PCR in HeLa and A549 cells infected with naked MV-Edm or GOS/MV-Edm in $\mathrm{FA}^{+}$or $\mathrm{FA}^{-}$medium (Fig. $5 \mathrm{c}$ and $\mathrm{d}$ ). These data confirm that the facilitating effect of PEI-GOS-PEG-FA on MV-Edm to enter cancer cells is dependent on the FR.

To determine whether GOS/MV-Edm enabled MVEdm to enter into the cells by the FR rather than the MV-Edm receptor (CD46), we studied whether GOS/ MV-Edm could infect murine cells that lack the MV-Edm receptor (CD46) and have an abundance of the FA receptor. Indeed, the murine cells (4 T1 and LLC cells) almost did not express CD46, while the human cells (HeLa and A549 cells) strongly expressed this molecule (Fig. 5e). In addition to expressing CD46, 4 T1 and LLC cells express a certain amount of FR (Fig. 5f). Interestingly, observation from fluorescence microscopy showed that GOS/MVEdm-eGFP, rather than the naked MV-Edm, could infect the murine $4 \mathrm{~T} 1$ and LLC cells but the naked MV-Edm could not (Fig. 5g). In addition, after entering cancer cells that were facilitated by PEI-GOS-PEG-FA, MV-Edm could replicate in the murine cells, which express a certain amount of FR (Fig. 5h). However, this phenomenon was not observed in naked MV-Edm-infected murine cells. These data show that PEI-GOS-PEG-FA enables MVEdm to enter the cells through the FR.

\section{GOS/MV-Edm remains infective in the presence of antimeasles neutralizing serum}

The clinical application of MV-Edm as an oncolytic virus is limited by the neutralization of preexisting

Table 4 Characterization of MV-Edm encapsulation in GOS

\begin{tabular}{llllllll}
\hline & & & & \multicolumn{3}{c}{ PEI-GOS-PEG-FA: MV-Edm(v/v ratio) } \\
\cline { 3 - 7 } & PEI-GOS- -PEG-FA & MV-Edm & $2: 1$ & $3: 1$ & $4: 1$ & $5: 1$ \\
\hline Size $(\mathrm{nm})$ & 48.09 & 241.4 & 271.2 & 290.8 & 1164 & 1154 \\
Zeta $(\mathrm{mV})$ & 40.2 & -21.2 & -10.2 & -9.9 & -2.43 & 6.57 \\
\hline
\end{tabular}



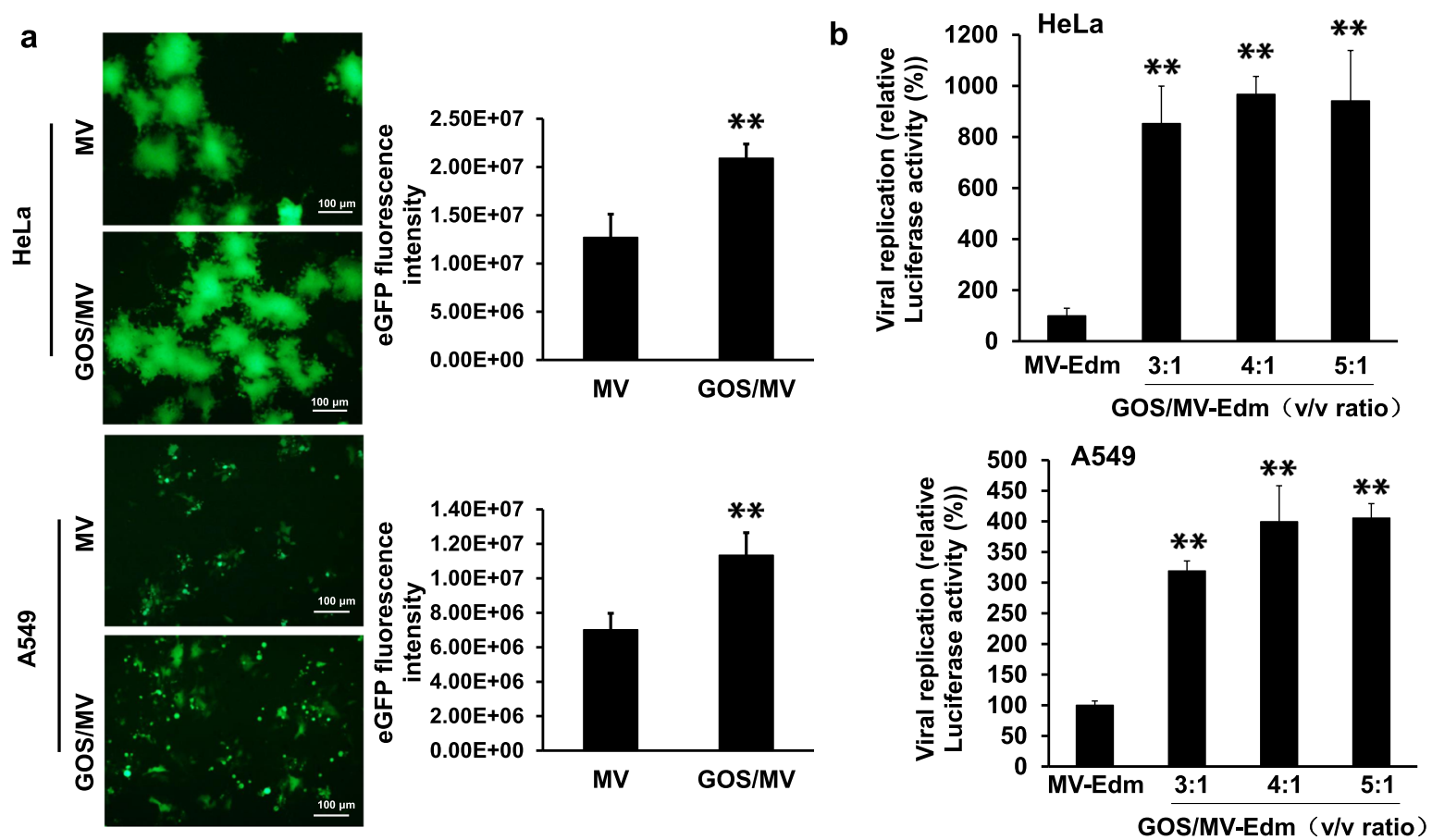

C
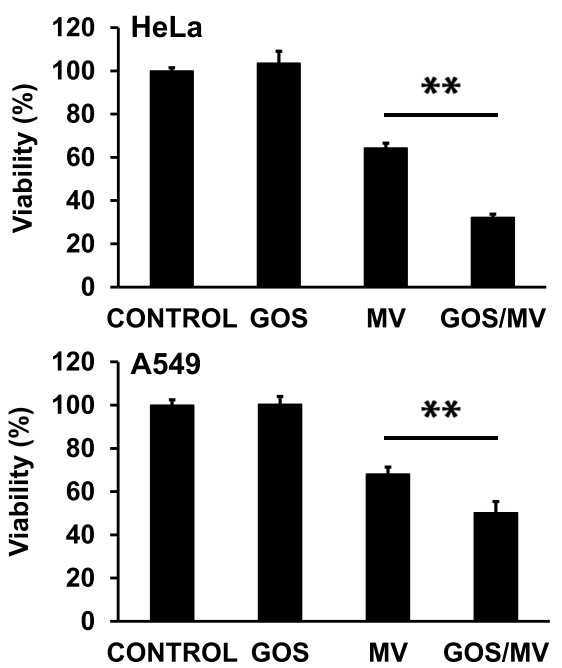

e

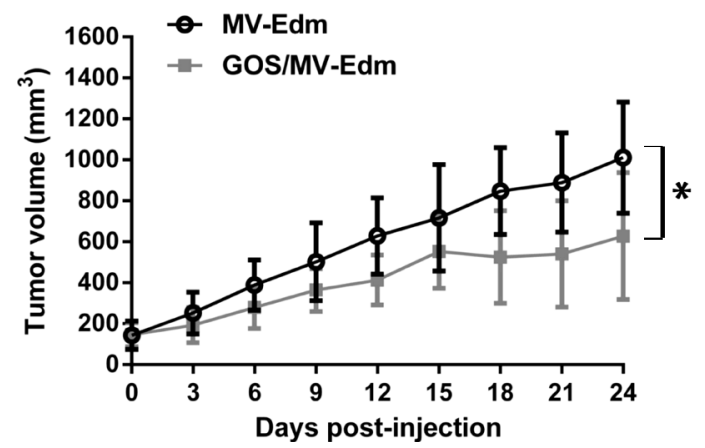

d
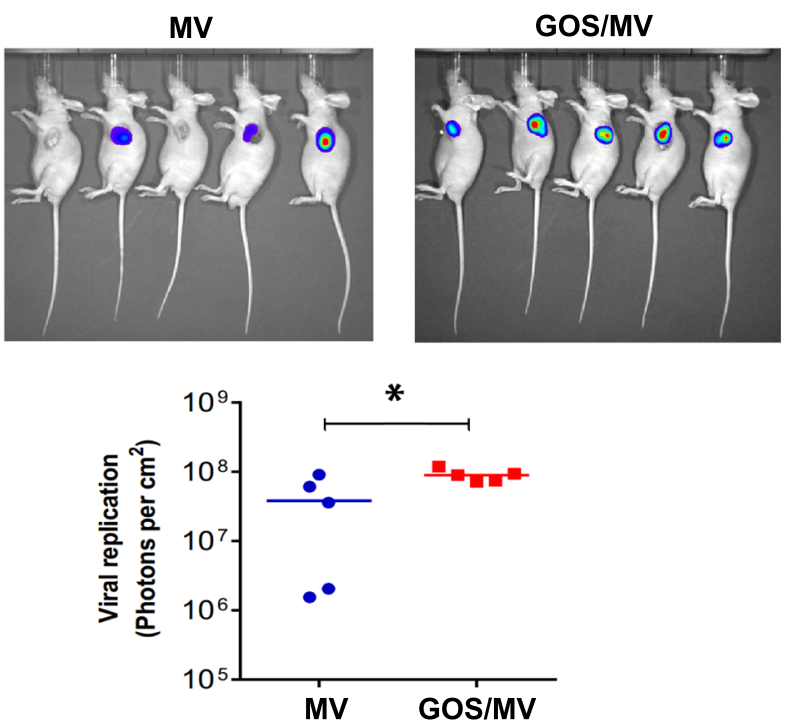

Fig. 4 (See legend on next page.) 
(See figure on previous page.)

Fig. 4 Encapsulation of MV-Edm in GOS promoted viral infection and improved oncolytic effects, and intratumorally injected GOS/MV-Edm significantly inhibited the tumor growth of mice in vivo. a HeLa and A549 cells were infected with MV-Edm-eGFP and GOS/MV-Edm-eGFP at an MOI of 0.5 and $5 \mu \mathrm{g} / \mathrm{ml} \mathrm{PEI-GOS-PEG-FA.} \mathrm{The} \mathrm{fluorescence} \mathrm{images} \mathrm{of} \mathrm{the} \mathrm{cells} \mathrm{and} \mathrm{the} \mathrm{GFP} \mathrm{fluorescence} \mathrm{intensities} \mathrm{were} \mathrm{measured} \mathrm{at} 48 \mathrm{~h}$ postinfection. $\mathbf{b}$ The HeLa and A549 cells were infected with MV-Edm-Luc or GOS/MV-Edm-Luc at an MOI of 0.5, and the luciferase activity was monitored based on its luminescence $48 \mathrm{~h}$ after the virus injection. c Cell death was quantified by trypan blue exclusion in HeLa and A549 cells at $48 \mathrm{~h}$ postinfection. Similar results were obtained in three independent experiments. Mean of triplicates, \# $p$ indicates not significant, ${ }^{*} p<0.05,{ }^{* *} p<0.01$. d A total of $5 \times 10^{6}$ HeLa cells $/ 0.1 \mathrm{ml} /$ mouse was subcutaneously injected into the left flanks of 5- to 6-week-old male Foxn1 nu mut/mut mice; 10 days later, the tumors became visible. The mice were randomized into two groups ( $n=5$ for each group). Then, two groups of mice were intratumorally injected with MVEdm-Luc ( $2 \times 10^{6}$ TCID50 per mouse). Luciferase activity was monitored by an in vivo luminescence imaging system $72 \mathrm{~h}$ after virus injection (left panel). Photons per $\mathrm{cm}^{2}$ tumor were quantified (lower panel). e On the first day and the fourteenth day after implantation of HeLa cells, naked MVEdm or GOS/MV-Edm were injected peritumorally into the mice bearing HeLa tumors. The volumes of tumors treated with GOS/MV-Edm (black line) were clearly smaller than those treated with naked MV-Edm (gray line). Means are shown ( $n=5$ of each), ${ }^{*} p<0.05,{ }^{* *} p<0.01$

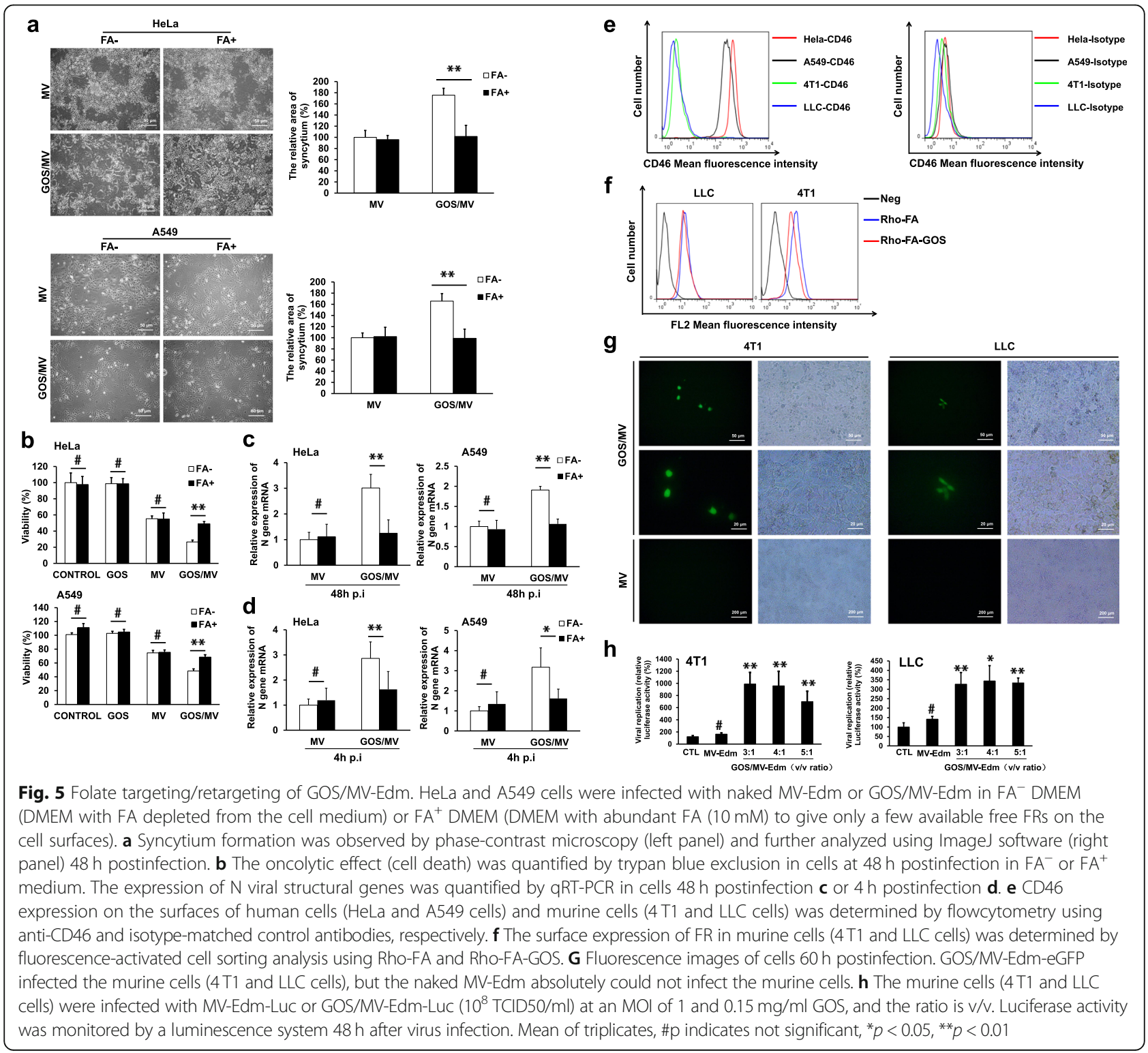


measles antibodies in most patients due to previous immunization or prior oncolytic viral therapy $[16,36]$. To investigate whether the GOS could protect MV-Edm from neutralization by human measles antibodies, plasma with a high titer of neutralizing antibodies was diluted 16 times, followed by serial one-half dilutions up to 1:128. The serum with a high titer of neutralizing antibodies was obtained from a healthy donor with immunity against measles as defined by high levels of measles antibodies using the PRN assay [37]. As expected, MV-Edm infection towards HeLa and A549 cells was completely blocked when undiluted human immune MV serum was used. After incubation with the neutralizing plasma, MV-Edm encapsulated in PEI-GOS-PEG-FA had a markedly stronger oncolytic effect than the naked MV-Edm incubated with the neutralizing plasma (Fig. 6a). Furthermore, fluorescence microscopy showed that MV-Edm-eGFP replicated more rapidly in GOS/MV-Edm cells than in naked MV-Edm-infected cells following incubation with the neutralizing antibody (Fig. 6b). These results suggest that GOS/MV-Edm is more resistant to neutralizing antibodies and that GOS/MV-Edm is capable of infecting cancer cells despite continuous exposure to human immune serum containing measles antibodies.

In addition, the in vivo data show that GOS/MV-Edm was more efficient in targeting the HeLa tumor than naked MV-Edm in the presence of antimeasles virus antibodies (Fig. 6c).

\section{GOS/MV-Edm significantly improves the antitumor efficacy in antiserum passively immunized tumor-bearing mice}

Next, to elucidate whether the resistance of GOS/MVEdm to neutralizing antibodies could be observed in vivo, we evaluated the in vivo anticancer effects of GOS/MVEdm and naked MV-Edm against HeLa human cervical cancer cells using a tumor-bearing nude mouse model recombined with human serum containing antimeasles antibodies. On the first and fourteenth days after inoculation of the HeLa cells, either naked MV-Edm or GOS/ MV-Edm was intravenously injected into the HeLa tumor-burdened mice in the presence or absence of $500 \mu \mathrm{l}$ of human immune serum containing measles antibodies. Mice received GOS/MV-Edm displayed a slightly prolonged survival compared with those treated with MVEdm, although no significant difference reached. However, GOS/MV-Edm injection led to a significant survival benefit for HeLa tumor-bearing mice compared with those receiving MV-Edm in the presence of the MV-neutralizing serum antibodies (Fig. 7). To be noted, the antitumor efficacy of naked MV-Edm was completely abrogated when mice were administrated with MV-neutralizing antibodies. In the contrast, the GOS/MV-Edm remained its capability to prolong the mice survival in the presence of neutralizing antibodies. These data reveal that GOS/MV-Edm is more resistant to the neutralizing antibody and displays a higher therapeutic effect in vivo than naked MV-Edm.

\section{Discussion}

Preexisting virus-neutralizing antibodies and inefficient tumor-targeted delivery are major hurdles in the road to improving the oncolytic effect of viral therapies on malignant carcinomas [36, 38-40]. In this study, we showed that replicating oncolytic MV-Edm capsulated within PEI-GOS-PEG-FA may be a promising approach to overcoming these hurdles. The present study has shown that the GOS/MV-Edm complexes led to enhanced infecting efficiency, increased resistance to neutralizing measles antibodies in human serum in a concentrationdependent manner, and elevated efficiency of targeted delivery. Subsequently, GOS/MV-Edm treatment displayed elevated antitumor effects in vivo in terms of reduced tumor volume and prolonged the life of tumorbearing mice. The in vivo efficacy of GOS/MV-Edm is mainly based on active targeting, retention effects and permeability [41]. Fortunately, the in vivo data showed encouraging results when the treatment was translated from in vitro to in vivo. In addition, no significant GOSrelated side effects were observed in this study.

For the utilization of oncolytic viruses in the clinical treatment of cancer, it would be difficult for viruses that were delivered systemically to reach the tumor sites. Despite the promising preclinical results of MV-Edm as a selective cancer therapy, MV-Edm has shown oncolytic efficacy only for patients without antimeasles virus antibodies in clinical trials [42]. Intravenous administration has been shown to result in sequestration due to macrophage uptake and preexisting neutralizing antibodies $[13,16]$. Therefore, various carriers are promising agents with considerable potential as oncolytic therapeutics. Previously, cell carriers were designed to solve these problems by protecting oncolytic viruses from immune clearance and delivering viruses to tumor loci $[13,16]$. Cell carriers have inherent tumor tropism by which they could deliver the oncolytic virus more specifically to tumor sites. Thus, the specifically designed cell carriers need to be designed for each person rather than a general population; otherwise, they could elicit immune rejection because of "nonself" components [43]. One phase I clinical trial for ovarian cancer used autologous/patient-derived mesenchymal stem cells as oncolytic measles virus carriers [44]. These challenges would cause the treatment to be unaffordable for the general public and significantly prolong the time of therapy. In addition, traditional cell carriers suffer from several other drawbacks, such as logistical, immunological and ethical considerations [44]. Recently, an in vitro method for the liposomal encapsulation 


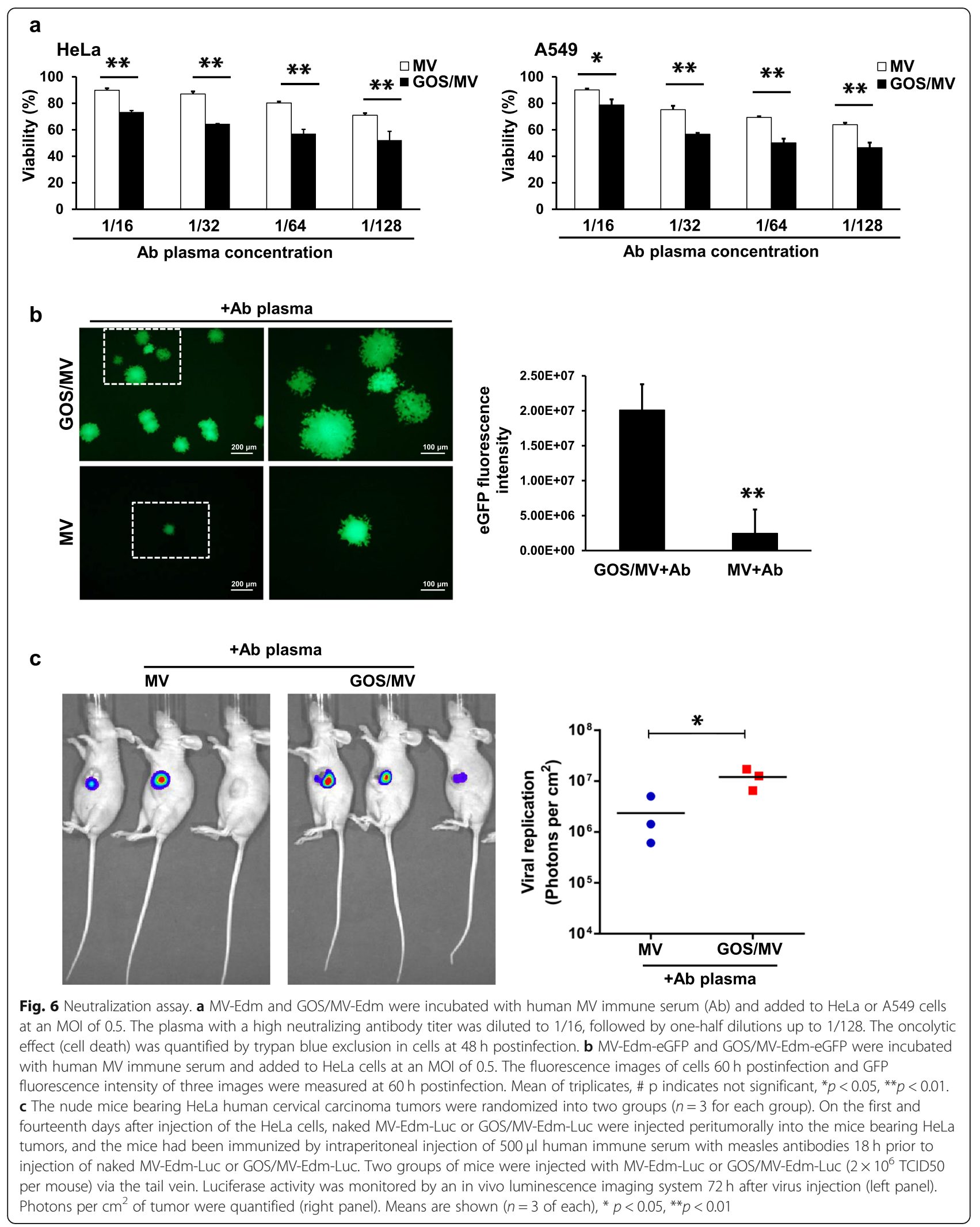




\section{Survival Time}

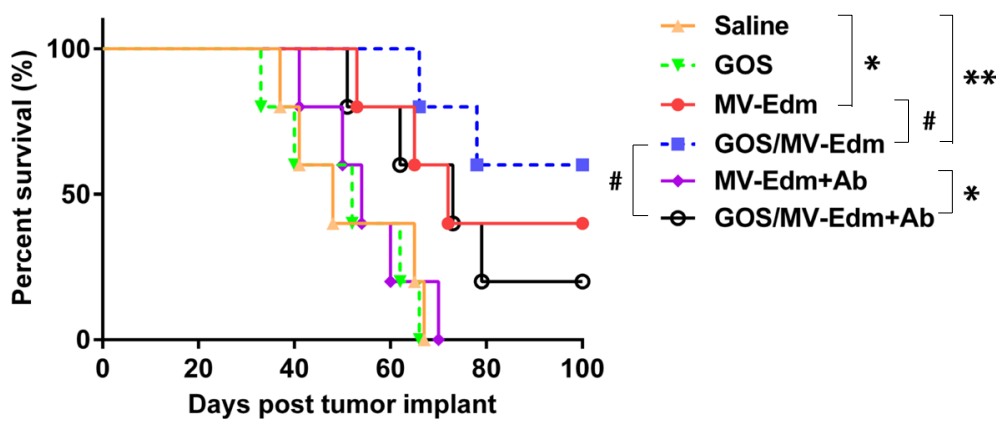

Fig. $7 \mathrm{MV}$-Edm protection by GOS in vivo. The nude mice bearing HeLa human cervical carcinoma tumors were randomized into five groups ( $n=5$ for each group). On day 1 and 14 after inoculation of HeLa cells, mice received peritoneal injection of $500 \mu$ human immune serum containing measles antibodies for $18 \mathrm{~h}$ followed by intravenous injection of either naked MV-Edm (purple line) or GOS/MV-Edm (black line). Or mice received the same volume of saline for $18 \mathrm{~h}$ followed by intravenous injection of either naked MV-Edm (red line) or GOS/MV-Edm (blue line). The mice treated with saline alone (orange line) or PEI-GOS-PEG-FA alone (green line) were used as controls. Survival of the mice was determined and plotted for survival analysis. Mice were euthanized when the tumor volume reached to $2 \mathrm{~cm} 3$ or when they experienced intolerable suffering. All mice surviving at day 100 were euthanized at the end of the study. Statistical testing was performed by log-rank test. \# $p$ indicates not significant, ${ }^{*} p<0.05,{ }^{* *} p<0.01$

of an oncolytic adenovirus was developed, and the encapsulated viruses remained able to infect cancer cells. Although this study remains restricted to in vitro data and its effect in vivo remains unclear, this novel delivery strategy has potential for oncolytic therapy [33]. Compared to traditional cell carriers, these nanovehicles have many unique advantages, such as mass synthesis, functional decoration, multiple detection, and cost-effectiveness [41]. In this study, complete PEI-GOS-PEG-FA encapsulation reduced the risk of adverse immune responses when the virus was administered at a high dose, and the encapsulation reduced clearance from the bloodstream due to neutralizing antibodies. In addition, the increased infection efficiency of GOS/MV-Edm caused a stronger antitumor effect, which eventually prolonged the lives of tumorbearing mice. Our investigations regarding the dynamics of circulation and tumor accumulation after intratumoral or intravenous administration of GOS/MV-Edm assess the efficacy of the platform in vivo well. A better comprehension of the cellular release of the MV-Edm from the GOS capsulation may allow the development of an improved oncolytic virus delivery platform. Generally, virus release in a cell may be due to changes in the environmental conditions between the extracellular matrix and the cytoplasm.

On the other hand, the naked MV-Edm could enter numerous types of tumor cells via the ubiquitously expressed protein CD46 [45]. Recently, some chimeric measles viruses were recombined with antigens for tumor-specific ligands such as CD20, CD133, and synthetic microRNA for tumor-targeting sequences [46, 47], however, these chimeric viruses with retargeted tropisms also raised safety concerns, including the ability of these chimeric virus mutations to impair cell entry [48] and their limited specificity for certain tumor types. Clearly, there is an urgent need to develop a generally applicable platform that can target tumor sites. In this study, GOS/ MV-Edm showed specific and efficient targeting to tumor cells, which was crucial for therapeutic efficacy. GOS is a promising biological therapy carrier due to its excellent biological compatibility and clear targeting movement after decoration [41, 49]. The expression of folate receptor, folic acid (FA)-binding protein, is elevated in many types of cancer cells, and GOS functionalizd with FA is widely used as a strategy for cancer-targeting delivery. As a ligand, FA could be covalently conjugated to GOS and confer a tumor-targeted delivery [50, 51]. In our study, we developed a novel strategy to achieve both virus protection and targeted release within the tumor by encapsulating oncolytic measles virus and conjugating pegylated folate. These in vivo data showed that GOS/MV-Edm had effective and targeted oncolytic properties even when exposed to neutralizing antibodies. However, the exact release process of MV-Edm from GOS is still unclear. Further investigations regarding the release mechanism and stability of GOS/MVEdm in blood circulation are needed to elucidate the efficacy of the strategy in vivo.

\section{Conclusions}

In this study, it was shown that the encapsulation of oncolytic MV-Edm within PEI-GOS-PEG-FA (GOS/MV-Edm) has the potential to improve the oncolytic effect of viral therapies on malignant carcinomas by protecting viruses from neutralization by antivirus antibodies in human blood, extending the circulation time and improving the ability of tumor targeting (Scheme. 1). Our current work 


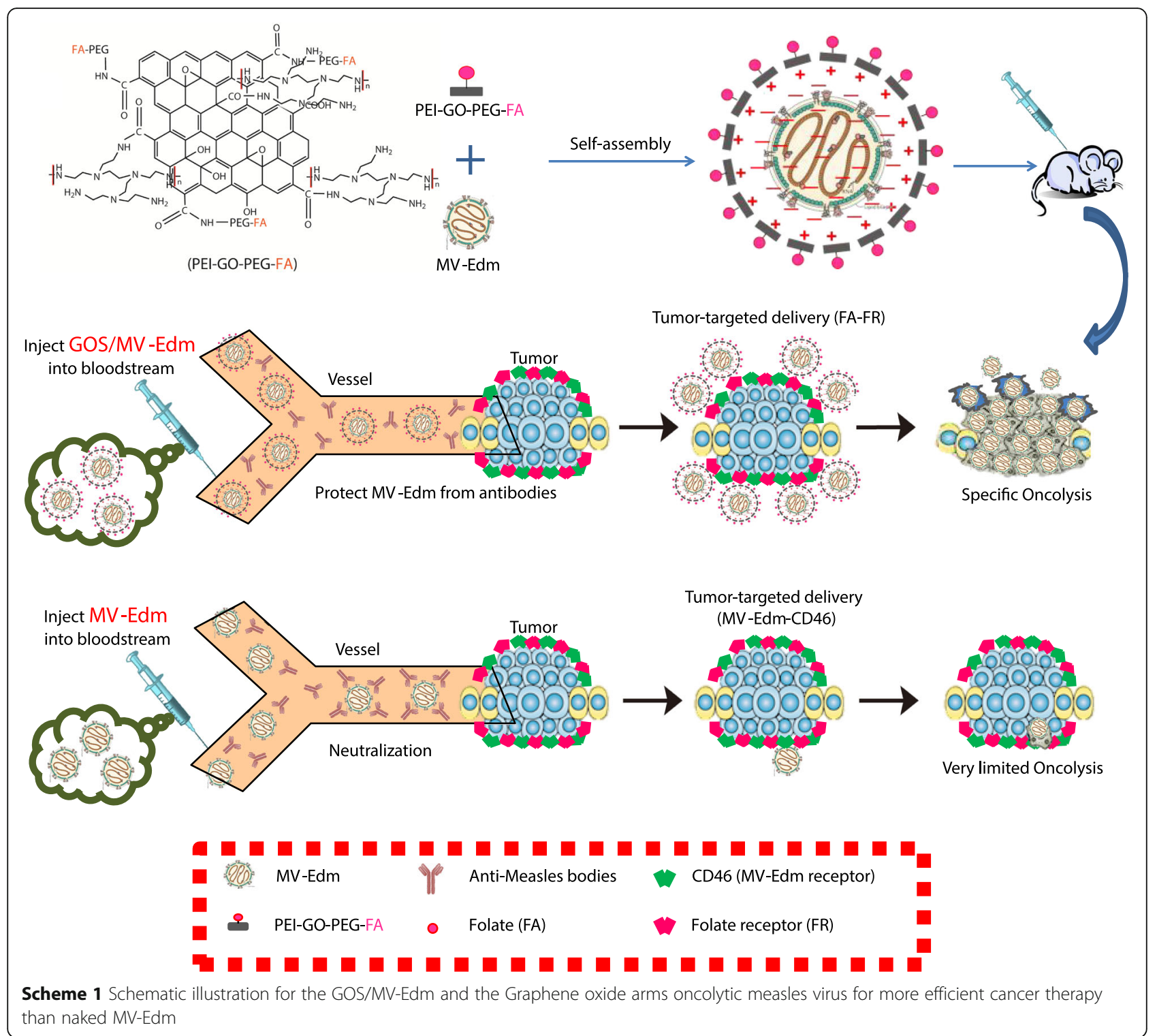

exploits the fact that GOS/MV-Edm was more resistant to neutralizing antibodies and displayed a higher therapeutic effect in vivo than naked MV-Edm. In summary, a novel, nontoxic encapsulation method was developed to enhance the targeted delivery of MV-Edm to cancer cells even with antivirus antibodies. These findings could stimulate preclinical and clinical studies that will explore the therapeutic aspects of this strategy.

\section{Abbreviations}

DIPEA: N, N-diisopropylethylamine; DMF: Dimethylformamide; EDC: N-(3dimethylaminopropyl-N'-ethylcarbodiimide) hydrochloride; FA: Folic acid; FTIR: Fourier transform infrared spectroscopy; GOS: Graphene oxide sheets: MES: 2-morpholinoethane sulfonic acid monohydrate; MV-Edm: Attenuated measles virus of the Edmonston strain; NHS: N-hydroxysuccinimide; OVs: Oncolytic viruses; PEG: Polyethylene glycol; PEl: Polyethyleneimine
Acknowledgements

Not applicable.

\section{Authors' contributions}

Conception and design: JW, JW, MX; Development of methodology: MX, DL, JD; Acquisition of data (provided animals, provided facilities, etc.): MX, DL, JD, $M Z_{;}$Analysis and interpretation of data (e.g., statistical analysis, biostatistics, computational analysis): MX, DL, JD; Writing, review, and/or revision of the manuscript: MX, JW, JW, GM; Administrative, technical, or material support (i.e., reporting or organizing data, constructing databases): JW, JW, MX, DL; Study supervision: JW. All authors read and approved the final manuscript.

\section{Funding}

This project was supported by The National Natural Science Foundation of China $(81602702,81773255,81700037$ and 81972888), the Six talent peaks project in Jiangsu Province to Jiwu Wei, the primary Research \& Development Plan of Jiangsu Province (BE2018701), and the Natural Science Foundation of Jiangsu Province of China (BK20160126 and BK20171098). 


\section{Availability of data and materials}

All data analyzed during this study are included in this manuscript.

\section{Ethics approval and consent to participate}

All animal studies were approved by the Animal Care Committee of Nanjing University.

\section{Consent for publication}

All authors give consent for the publication of the manuscript.

\section{Competing interests}

The authors declared that they have no competing interests

\section{Author details Nanjing University, Nanjing 210008, China. ${ }^{3}$ Jiangsu Key Laboratory of China. ${ }^{4}$ The Affiliated Drum Tower Hospital, Medical School of Nanjing University, Nanjing 210008, China. \\ Received: 7 March 2019 Accepted: 3 September 2019 Published online: 18 September 2019}

'Department of Laboratory Medicine, The Affiliated Drum Tower Hospital, Medical School of Nanjing University, Nanjing 210008, China. ${ }^{2}$ Department of Hepatobiliary Surgery, The Affiliated Drum Tower Hospital, Medical School of Molecular Medicine, Medical School of Nanjing University, Nanjing 210093,

\section{References}

1. Robinson S, Galanis E. Potential and clinical translation of oncolytic measles viruses. Expert Opin Biol Ther. 2017;17:353-63.

2. Bartlett DL, Liu Z, Sathaiah M, Ravindranathan R, Guo Z, He Y, Guo ZS. Oncolytic viruses as therapeutic cancer vaccines. Mol Cancer. 2013;12:103.

3. Russell SJ, Barber GN. Oncolytic viruses as antigen-agnostic Cancer vaccines. Cancer Cell. 2018;33:599-605.

4. Russell SJ, Peng KW. Oncolytic Virotherapy: a contest between apples and oranges. Mol Ther. 2017;25:1107-16.

5. Hasegawa K, Pham L, O'Connor MK, Federspiel MJ, Russell SJ, Peng KW. Dual therapy of ovarian cancer using measles viruses expressing carcinoembryonic antigen and sodium iodide symporter. Clin Cancer Res. 2006;12:1868-75.

6. Wei J, Wahl J, Nakamura T, Stiller D, Mertens T, Debatin KM, Beltinger C. Targeted release of oncolytic measles virus by blood outgrowth endothelial cells in situ inhibits orthotopic gliomas. Gene Ther. 2007;14:1573-86.

7. Phuong LK, Allen C, Peng KW, Giannini C, Greiner S, TenEyck CJ, Mishra PK, Macura SI, Russell SJ, Galanis EC. Use of a vaccine strain of measles virus genetically engineered to produce carcinoembryonic antigen as a novel therapeutic agent against glioblastoma multiforme. Cancer Res. 2003;63:2462-9.

8. Peng KW, Ahmann GJ, Pham L, Greipp PR, Cattaneo R, Russell SJ. Systemic therapy of myeloma xenografts by an attenuated measles virus. Blood. 2001;98:2002-7.

9. Allen C, Opyrchal M, Aderca I, Schroeder MA, Sarkaria JN, Domingo E, Federspiel MJ, Galanis E. Oncolytic measles virus strains have significant antitumor activity against glioma stem cells. Gene Ther. 2013;20:444-9.

10. Johnson DB, Puzanov I, Kelley MC. Talimogene laherparepvec (T-VEC) for the treatment of advanced melanoma. Immunotherapy. 2015;7:611-9.

11. Galanis E. Therapeutic potential of oncolytic measles virus: promises and challenges. Clin Pharmacol Ther. 2010;88:620-5.

12. lankov ID, Blechacz B, Liu C, Schmeckpeper JD, Tarara JE, Federspiel MJ, Caplice N, Russell SJ. Infected cell carriers: a new strategy for systemic delivery of oncolytic measles viruses in cancer virotherapy. Mol Ther. 2007; 15:114-22.

13. Castleton A, Dey A, Beaton B, Patel B, Aucher A, Davis DM, Fielding AK. Human mesenchymal stromal cells deliver systemic oncolytic measles virus to treat acute lymphoblastic leukemia in the presence of humoral immunity. Blood. 2014;123:1327-35.

14. Alcayaga-Miranda F, Cascallo M, Rojas JJ, Pastor J, Alemany R. Osteosarcoma cells as carriers to allow antitumor activity of canine oncolytic adenovirus in the presence of neutralizing antibodies. Cancer Gene Ther. 2010;17:792-802.

15. Willmon C, Harrington K, Kottke T, Prestwich R, Melcher A, Vile R. Cell carriers for oncolytic viruses: fed ex for cancer therapy. Mol Ther. 2009; 17(10):1667-76.
16. Ong HT, Federspiel MJ, Guo CM, Ooi LL, Russell SJ, Peng KW, Hui KM. Systemically delivered measles virus-infected mesenchymal stem cells can evade host immunity to inhibit liver cancer growth. J Hepatol. 2013;59:999-1006.

17. Pattni BS, Chupin W, Torchilin VP. New developments in liposomal drug delivery. Chem Rev. 2015;115:10938-66.

18. Zhang H, Bai M, Deng T, Liu R, Wang X, Qu Y, Duan J, Zhang L, Ning T, Ge S, Li H, Zhou L, Liu Y, Huang D, Ying G, Ba Y. Cell-derived microvesicles mediate the delivery of miR-29a/c to suppress angiogenesis in gastric carcinoma. Cancer Lett. 2016;375:331-9.

19. Tian J, Luo Y, Huang L, Feng Y, Ju H, Yu BY. Pegylated folate and peptidedecorated graphene oxide nanovehicle for in vivo targeted delivery of anticancer drugs and therapeutic self-monitoring. Biosens Bioelectron. 2016; 80:519-24.

20. Chanburee S, Tiyaboonchai W. Enhanced intestinal absorption of curcumin in Caco-2 cell monolayer using mucoadhesive nanostructured lipid carriers. J Biomed Mater Res B Appl Biomater. 2018;106:734-41.

21. Zhang M, Xiao B, Wang H, Han MK, Zhang Z, Viennois E, Xu C, Merlin D. Edible ginger-derived Nano-lipids loaded with doxorubicin as a novel drugdelivery approach for Colon Cancer therapy. Mol Ther. 2016;24:1783-96.

22. Feng L, Yang X, Shi X, Tan X, Peng R, Wang J, Liu Z. Polyethylene glycol and polyethylenimine dual-functionalized nano-graphene oxide for photothermally enhanced gene delivery. Small. 2013;9:1989-97.

23. Wu SY, An SS, Hulme J. Current applications of graphene oxide in nanomedicine. Int J Nanomedicine. 2015;10:9-24.

24. Patel SC, Lee S, Lalwani G, Suhrland C, Chowdhury SM, Sitharaman B. Graphene-based platforms for cancer therapeutics. Ther Deliv. 2016;7:101-16.

25. Liu J, Cui L, Losic D. Graphene and graphene oxide as new nanocarriers for drug delivery applications. Acta Biomater. 2013;9:9243-57.

26. Sun X, Liu Z, Welsher K, Robinson JT, Goodwin A, Zaric S, Dai H. Nanographene oxide for cellular imaging and drug delivery. Nano Res. 2008;1: 203-12.

27. Chen GY, Chen CL, Tuan HY, Yuan PX, Li KC, Yang HJ, Hu YC. Graphene oxide triggers toll-like receptors/autophagy responses in vitro and inhibits tumor growth in vivo. Adv Healthc Mater. 2014;3:1486-95.

28. Gurunathan S, Han JW, Kim JH. Green chemistry approach for the synthesis of biocompatible graphene. Int J Nanomedicine. 2013;8:2719-32.

29. Yang K, Feng L, Hong H, Cai W, Liu Z. Preparation and functionalization of graphene nanocomposites for biomedical applications. Nat Protoc. 2013;8: 2392-403.

30. Silvestri B, Guarnieri D, Luciani G, Costantini A, Netti PA, Branda F. Fluorescent (rhodamine), folate decorated and doxorubicin charged, PEGylated nanoparticles synthesis. J Mater Sci Mater Med. 2012;23:1697-704.

31. Yin D, Li Y, Lin H, Guo B, Du Y, Li X, Jia H, Zhao X, Tang J, Zhang L. Functional graphene oxide as a plasmid-based Stat3 siRNA carrier inhibits mouse malignant melanoma growth in vivo. Nanotechnology. 2013;24: 105102.

32. Sui ZY, Cui Y, Zhu JH, Han BH. Preparation of three-dimensional graphene oxide-polyethylenimine porous materials as dye and gas adsorbents. ACS Appl Mater Interfaces. 2013;5:9172-9.

33. Mendez N, Herrera V, Zhang L, Hedjran F, Feuer R, Blair SL, Trogler WC, Reid TR, Kummel AC. Encapsulation of adenovirus serotype 5 in anionic lecithin liposomes using a bead-based immunoprecipitation technique enhances transfection efficiency. Biomaterials. 2014;35:9554-61.

34. Raniolo S, Vindigni G, Ottaviani A, Unida V, lacovelli F, Manetto A, Figini M, Stella L, Desideri A, Biocca S. Selective targeting and degradation of doxorubicin-loaded folate-functionalized DNA nanocages. Nanomedicine. 2018;14:1181-90.

35. Kam NW, O'Connell M, Wisdom JA, Dai H. Carbon nanotubes as multifunctional biological transporters and near-infrared agents for selective cancer cell destruction. Proc Natl Acad Sci U S A. 2005;102:11600-5.

36. Ferguson MS, Lemoine NR, Wang Y. Systemic delivery of oncolytic viruses: hopes and hurdles. Adv Virol. 2012;2012:805629. https://doi.org/10.1155/2012/805629.

37. Ratnam S, Gadag V, West R, Burris J, Oates E, Stead F, Bouilianne N. Comparison of commercial enzyme immunoassay kits with plaque reduction neutralization test for detection of measles virus antibody. J Clin Microbiol. 1995;33:811-5.

38. Audet S, Virata-Theimer ML, Beeler JA, Scott DE, Frazier DJ, Mikolajczyk MG, Eller N, Chen FM, Yu MY. Measles-virus-neutralizing antibodies in intravenous immunoglobulins. J Infect Dis. 2006;194:781-9.

39. Nobre FA, Gonzalez IG, Simao RM, de Moraes Pinto MI, Costa-Carvalho BT. Antibody levels to tetanus, diphtheria, measles and varicella in patients with 
primary immunodeficiency undergoing intravenous immunoglobulin therapy: a prospective study. BMC Immunol. 2014;15:26.

40. Marelli G, Howells A, Lemoine NR, Wang Y. Oncolytic viral therapy and the immune system: a double-edged sword against Cancer. Front Immunol. 2018;9:866.

41. Reina G, Gonzalez-Dominguez JM, Criado A, Vazquez E, Bianco A, Prato M. Promises, facts and challenges for graphene in biomedical applications. Chem Soc Rev. 2017:46:4400-16.

42. Russell SJ, Federspiel MJ, Peng KW, Tong C, Dingli D, Morice WG, Lowe V, O'Connor MK, Kyle RA, Leung N, Buadi FK, Rajkumar SV, Gertz MA, Lacy MQ, Dispenzieri A. Remission of disseminated cancer after systemic oncolytic virotherapy. Mayo Clin Proc. 2014;89:926-33.

43. Ran L, Tan X, Li Y, Zhang H, Ma R, Ji T, Dong W, Tong T, Liu Y, Chen D, Yin X, Liang X, Tang K, Ma J, Zhang Y, Cao X, Hu Z, Qin X, Huang B. Delivery of oncolytic adenovirus into the nucleus of tumorigenic cells by tumor microparticles for virotherapy. Biomaterials. 2016;89:56-66.

44. Roy DG, Bell JC. Cell carriers for oncolytic viruses: current challenges and future directions. Oncolytic Virother. 2013;2:47-56.

45. Cattaneo R, Russell SJ. How to develop viruses into anticancer weapons. PLoS Pathog. 2017;13:e1006190.

46. Lal S, Raffel C. Using Cystine knot proteins as a novel approach to retarget oncolytic measles virus. Mol Ther Oncolytics. 2017;7:57-66.

47. Bach P, Abel T, Hoffmann C, Gal Z, Braun G, Voelker I, Ball CR, Johnston IC, Lauer UM, Herold-Mende C, Muhlebach MD, Glimm H, Buchholz CJ. Specific elimination of CD133+ tumor cells with targeted oncolytic measles virus. Cancer Res. 2013:73:865-74.

48. Aref S, Bailey K, Fielding A. Measles to the rescue: a review of oncolytic measles virus. Viruses. 2016:8:10

49. Georgakilas V, Tiwari JN, Kemp KC, Perman JA, Bourlinos AB, Kim KS, Zboril R. Noncovalent functionalization of graphene and graphene oxide for energy materials, biosensing, catalytic, and biomedical applications. Chem Rev. 2016;116:5464-519,

50. Geersing A, de Vries RH, Jansen G, Rots MG, Roelfes G. Folic acid conjugates of a bleomycin mimic for selective targeting of folate receptor positive cancer cells. Bioorg Med Chem Lett. 2019;29:1922-7.

51. Zagami R, Rapozzi V, Piperno A, Scala A, Triolo C, Trapani M, Xodo LE, Monsu Scolaro L, Mazzaglia A. Folate-decorated amphiphilic Cyclodextrins as celltargeted Nanophototherapeutics. Biomacromolecules. 2019;20:2530-44.

\section{Publisher's Note}

Springer Nature remains neutral with regard to jurisdictional claims in published maps and institutional affiliations.

Ready to submit your research? Choose BMC and benefit from:

- fast, convenient online submission

- thorough peer review by experienced researchers in your field

- rapid publication on acceptance

- support for research data, including large and complex data types

- gold Open Access which fosters wider collaboration and increased citations

- maximum visibility for your research: over $100 \mathrm{M}$ website views per year

At $\mathrm{BMC}$, research is always in progress.

Learn more biomedcentral.com/submissions 